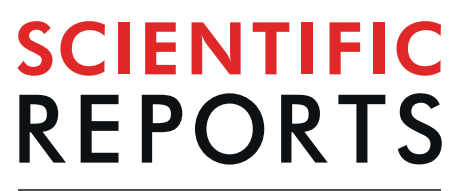

natureresearch

\title{
OPEN Intelligent Metal-Phenolic Metallogels as Dressings for Infected Wounds
}

Received: 25 April 2019

Accepted: 26 July 2019

Published online: 09 August 2019

\author{
Ha Thi Phuong Anh ${ }^{1}$, Chun-Ming Huang ${ }^{1} \&$ Chun-Jen Huang ${ }^{1,2,3}$
}

In this study, we report a metallogel developed based on metal-phenolic coordination of natural lowcost polyphenolic molecule and metal ions. Gelation occurs by mixing tannic acid (TA) and group (IV) titanium ions ( $\mathrm{Ti}^{\mathrm{iV}}$ ) to form TA-TiV gel. The TA-Tiv gel exhibits good capability to incorporate diverse

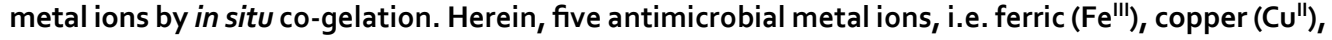
zinc $\left(\mathrm{Zn}^{\mathrm{II}}\right)$, cobalt $\left(\mathrm{Co}^{\mathrm{II}}\right)$ and nickel $\left(\mathrm{Ni}^{\mathrm{II}}\right)$ ions, were employed to include in TA-Ti' gels for developing intelligent dressings for infected wounds. The chemical and coordinative structures of TA-TiV metallogels were characterized by UV-Vis and Fourier-transform infrared (FT-IR) spectroscopies. Cytotoxicity of antimicrobial metallogels was explored by MTT assay with NIH 3T3 fibroblasts. The release of metal ions was evaluated by inductively coupled plasma mass spectrometry (ICP-MS), indicating the different releasing profiles upon the coordinative interactions of metal ions with TA. The formation and disassembly of metallogels are sensitive to the presence of acid and an oxidizer, $\mathrm{H}_{2} \mathrm{O}_{2}$, which are substances spontaneously generated in infected wounds due to the metabolic activity of bacteria and the intrinsic immune response. The $\mathrm{Cu}^{\prime \prime}$ releasing rates of TA-Ti' $-\mathrm{Cu}^{\prime \prime}$ metallogels at different $\mathrm{pH}$ values of 5.5, 7.4 and 8.5 have been studied. In addition, addition of $\mathrm{H}_{2} \mathrm{O}_{2}$ trigger fast release of Cu" as a result of oxidation of galloyl groups in TA. Consequently, the antimicrobial potency of TA-Ti' $-C U^{\prime \prime}$ metallogels can be simultaneously activated while the wounds are infected and healing. The antimicrobial property of metallogels against Gram-negative Escherichia coli, and Gram-positive Methicillin-Resistant Staphylococcus aureus (USA300) and Staphylococcus epidermidis has been investigated by agar diffusion test. In an animal model, the TA-Ti'v-Cull metallogels were applied as dressings for infected wounds, indicating faster recovery in the wound area and extremely lower amount of bacteria around the wounds, compared to TA-Til gels and gauze. Accordingly, the intelligent nature derived metallogels is a promising and potential materials for medical applications.

Infections occur when virulence factors expressed by one or more microorganisms in a wound outcompete the host immune system. Dissemination of microorganisms in tissue provokes a series of local and systemic host responses ${ }^{1}$. Complications of infected wounds depend on the pathogenicity of the microorganisms and on the immune competence of the host, manifesting as clinical signs, such as pain, heat, erythema, edema, tenderness, cellulitis and abscess. The infection in a wound can lead to an acute responses and delay the wound healing process $^{2}$. Bacteria such as methicillin-resistant Staphylococcus aureus (USA300), Escherichia coli and Staphylococcus epidermidis have been frequently isolated from infected wounds, and become common wound pathogens ${ }^{3}$.

It has been proven that the $\mathrm{pH}$ of a wound environment plays an important role in wound healing because it relates to antimicrobial activity and control infection, angiogenesis, oxygen release, and protease activity ${ }^{4}$. Bacterial infection leads to the $\mathrm{pH}$ fluctuation because of the complex process of healing, immune responses and bacterial metabolism. The $\mathrm{pH}$ has been found to fall to the value as low as 5.5 at the infection sites due to low-oxygen fermentation, triggering the production of lactic acid and acetic acid ${ }^{5-7}$. In addition, the production of hydrogen peroxide $\left(\mathrm{H}_{2} \mathrm{O}_{2}\right)$ in the infecting wounds is the first response of the immune system during inflammation to exert antimicrobial activity ${ }^{8,9} \cdot \mathrm{H}_{2} \mathrm{O}_{2}$ is known as a reactive oxygen species (ROS), which accounts for their versatility in mediating host defense against a broad range of pathogens. In addition, studies revealed that

${ }^{1}$ Department of Biomedical Sciences and Engineering, National Central University, Jhong-Li, Taoyuan, 320, Taiwan. ${ }^{2}$ Department of Chemical and Materials Engineering, National Central University, Jhong-Li, Taoyuan, 320, Taiwan. ${ }^{3}$ R\&D Center for Membrane Technology, Chung Yuan Christian University, 200 Chung Pei Rd., Chung-Li City, 32023, Taiwan. Correspondence and requests for materials should be addressed to C.-J.H. (email: cjhuang@ncu.edu.tw) 
$\mathrm{H}_{2} \mathrm{O}_{2}$ supports the healing process at a level of $\mu \mathrm{M}$ concentration by serving as a signaling molecule and stimulating an effector cells response $\mathrm{e}^{10,11}$. The endogenous substances allow to serve as an environmental stimulus to spontaneously trigger the antimicrobial reactions of medical devices. Therefore, $\mathrm{pH}$ - and $\mathrm{H}_{2} \mathrm{O}_{2}$-responsive antibiotic delivery systems have received considerable attention due to their great potential and easy applicability in the clinical treatment of infections ${ }^{5,12,13}$.

Antimicrobial properties of metal ions have been known and explored for many years ${ }^{14}$. Antibacterial metal ions, such as silver $\left(\mathrm{Ag}^{\mathrm{I}}\right)$, zinc $\left(\mathrm{Zn}^{\mathrm{II}}\right)$, cobalt $\left(\mathrm{Co}^{\mathrm{II}}\right)$, nickel $\left(\mathrm{Ni}^{\mathrm{II}}\right)$, iron $\left(\mathrm{Fe}^{\mathrm{III}}\right)$ and copper $\left(\mathrm{Cu}^{\mathrm{II}}\right)$, have been extensively used in artificial medical implants and devices due to their broad-spectrum antibacterial activity ${ }^{14-16}$. The toxicity of metals to bacteria is primarily related to strong affinities to biomolecules and production of ROS. Recent studies indicate that different metals cause discrete and distinct types of injuries to microbial cells as a result of protein dysfunction, oxidative stress or membrane damage ${ }^{17}$. Generally, metals appear to target multiple cellular processes, leading to pleiotropic effects on bacteria ${ }^{17}$.

Polyphenolic derivatives exist ubiquitously in nature. Their coordinative complexation with metal ions displays a remarkable degree of physico-chemical versatility that has already inspired an ever-growing number of applications as functional materials ${ }^{18-21}$. Harrington et al. indicated that catecholic amino acid-iron chelate complexes form the peculiar metallopolymeric structures, exhibiting a combination of high hardness and high extensibility ${ }^{21}$. Recently, Caruso's group demonstrated metal-phenolic complexation between different metals and natural polyphenolic tannic acid (TA) for assembly of conformal functional coatings ${ }^{20}$. Moreover, they reported a formation of metal-phenolic supramolecular metallogels by direct complexation of multitopic galloyl groups of $\mathrm{TA}$ and group (IV) transition metal of $\mathrm{Ti}^{\mathrm{IV}}{ }^{14}$. The metallogels represent excellent versatility to incorporate diverse metal ions, nanomaterials, and polymers via in situ co-gelation without affecting the fundamental gelation process. Additionally, the metallogels display $\mathrm{pH}$-modulated mechanical property, shape persistence, adhesiveness, optical transparency, tunable mechanical properties and self-healing capability ${ }^{14,20}$.

In this study, we attempted to develop antibacterial metallogels with $\mathrm{pH}$ - and $\mathrm{H}_{2} \mathrm{O}_{2}$-responsive properties as dressings for infected wounds. The metallogels were synthesized via co-gelation of TA, high-oxidation state $\mathrm{Ti}^{\mathrm{IV}}$ and antimicrobial metal ions for formation of three-dimensional metal-phenolic networks (MPNs). The antimicrobial metal ions of $\mathrm{Zn}^{\mathrm{II}}, \mathrm{Co}^{\mathrm{II}}, \mathrm{Ni}^{\mathrm{II}}, \mathrm{Fe}^{\mathrm{III}}$ and $\mathrm{Cu}^{\mathrm{II}}$ were included in the metallogels for comparative study in terms of their release profiles, cytotoxicity, and antimicrobial potency. Moreover, the antibacterial effect of metallogels can be triggered by acids originated from the metabolic activity of bacteria, and endogenously produced $\mathrm{H}_{2} \mathrm{O}_{2}$ after skin wound occurs upon disassembly of the MPNs. UV-vis spectroscopy and Fourier-transform infrared spectroscopy (FTIR) were employed for analysis of coordinative structures of metallogels. The metal ion release profiles and responsiveness of the metallogels to $\mathrm{pH}$ and $\mathrm{H}_{2} \mathrm{O}_{2}$ were determined by inductively coupled plasma mass spectrometry (ICP-MS). The antimicrobial properties and cytotoxicity of all metal ions were accessed by minimum inhibitory concentration (MIC) test and 3-(4,5-dimethylthiazol-2-yl)-2,5-diphenyl tetrazolium bromide (MTT) assay. The antimicrobial effect of metallogels against Gram-negative E. coli, and Gram-positive $S$. aureus and $S$. epidermidis was investigated by agar diffusion test. In an animal model, biocompatible $\mathrm{TA}-\mathrm{Ti}^{\mathrm{IV}}-\mathrm{Cu}^{\mathrm{II}}$ metallogels were developed as dressings for infected wounds on mice in comparison with $\mathrm{TA}-\mathrm{Ti}^{\mathrm{IV}}$ gels and gauze. Ultimately, the versatility and robustness, combined with the low cost, biocompatibility, ease, and scalability of the coordination-driven assembly make the metallogels excellent candidates for medical applications.

\section{Experimental Section}

Materials. Tannic acid (TA, ACS reagent), titanium (IV) bis (ammonium lactato) dihydroxide (Ti-BALDH) solutions $50 \mathrm{wt} \%$ in $\mathrm{H}_{2} \mathrm{O}$, iron (III) hexahydrate $\left(\mathrm{FeCl}_{3} \cdot 6 \mathrm{H}_{2} \mathrm{O}\right)$, copper (II) chloride $\left(\mathrm{CuCl}_{2}\right)$, cobalt (II) bromide $\left(\mathrm{CoBr}_{2}\right)$, nickel (II) chloride $\left(\mathrm{NiCl}_{2}\right)$, zinc (II) chloride $\left(\mathrm{ZnCl}_{2}\right)$, 2,6-dichlorophenolindophenol, trizma hydrochloride (Tris), copper assay kit and peroxidase from horseradish (HRP) lyophilized powder were purchased from Sigma-Aldrich. Phosphate buffer saline (PBS) was obtained from Acros Organics. Luria-Bertani (LB) and tryptic soy broth (TSB) were purchased from Gibco. MTT assay kit and sodium hydroxide $(\mathrm{NaOH})$ were acquired from Thermo Fisher Scientific. Dulbecco's Modified Eagle's Medium (DMEM) and fetal bovine serum (FBS) were purchased from Gibco. NIH 3T3 fibroblasts were obtained from Bioresource Collections and Research Center (BCRC), Taiwan. S. epidermidis ATCC12228, methicillin-resistant S. aureus (USA300, ATCC BAA-1718) and E. coli ATCC12435 were acquired from Bioresource Collections and Research Center in Taiwan. All the water used was purified to $18.2 \mathrm{~m} \Omega$ using a Millipore water purifications system, and filtered using a $0.22 \mu \mathrm{m}$ filter.

Preparation of antimicrobial metallogels. All solutions were prepared under a nitrogen atmosphere using standard Schlenk techniques. The preparation of $\mathrm{TA}-\mathrm{Ti}^{\mathrm{IV}}$ metallogels was referred to previous study ${ }^{14}$. Briefly, $5 \mathrm{wt} \%$ of TA solution was prepared in deionized water. The $\mathrm{pH}$ of the TA solution was adjusted to approximately 7 by adding $1 \mathrm{M} \mathrm{NaOH}$ solution. $50 \mathrm{wt}$.\% of Ti-BALDH stock solutions was then mixed with the TA solutions to afford a TA:Ti molar ratio of 1:5. The mixture was thoroughly shaken for $10 \mathrm{~s}$ to make sure all the components were well mixed and homogeneous. The mixed solution was left to stand for $20 \mathrm{~min}$ and the color of the solution turned from orange to red. The state of the solution was turned from sol to gel. The hydrogel was removed from the tube and denoted as $\mathrm{TA}-\mathrm{Ti}^{\mathrm{IV}}$.

The antimicrobial metal ions of $\mathrm{Fe}^{\mathrm{III}}, \mathrm{Cu}^{\mathrm{II}}, \mathrm{Co}^{\mathrm{II}}, \mathrm{Ni}^{\mathrm{II}}$ and $\mathrm{Zn}^{\mathrm{II}}$ were introduced individually for preparation of the metallogels by co-gelation. The $\mathrm{Ti}^{\mathrm{IV}}$ and antimicrobial metal ions were added into the TA solution, prepared as above mentioned. The mixed solution had a molar ratio of TA: $\mathrm{Ti}^{\mathrm{IV}}: \mathrm{M}$ to be $1: 4: 1$, where $\mathrm{M}$ is referred to the antimicrobial metal ions. The mixture was shaken with vortex for $10 \mathrm{~s}$ and then stood on a bench for $20 \mathrm{~min}$.

Spectroscopic characterizations of metallogels. UV-vis spectroscopy was used to examine the coordination reaction of $\mathrm{TA}$ and $\mathrm{Ti}^{\mathrm{IV}}$ in an aqueous solution. UV-vis spectra were obtained on a spectrophotometer (V-600, JASCO, MD) at room temperature. Three solutions were prepared prior to the measurements. Control 
samples of $\mathrm{TA}$ and $\mathrm{Ti}^{\mathrm{IV}}$ solutions were prepared in oxygen-free deionized water at concentrations of 0.1 and $0.3455 \mathrm{wt} \%$, respectively. The $\mathrm{pH}$ of the TA solution was controlled at 7 . The $\mathrm{TA}-\mathrm{Ti}^{\mathrm{IV}}$ solution was prepared as above mentioned.

Fourier-transform infrared spectroscopy (FTIR, Jasco FT/IR-410) was employed to analyze chemical and coordination structures of metallogels. $\mathrm{TA}-\mathrm{Ti}^{\mathrm{IV}}$ metallogels were dried in liquid nitrogen under reduced pressure for $4 \mathrm{~h}$. The dried $\mathrm{TA}-\mathrm{Ti}^{\mathrm{IV}}$ was grounded by a pestle and blended with $\mathrm{KBr}$. The mixed powder was compressed into a pellet. FTIR was operated in a wavenumber range of 400 to $4000 \mathrm{~cm}^{-1}$.

Release profiles of metal ions. Metal ion release profile was measured and recorded for $15 \mathrm{~h}$ using inductively coupled plasma-mass spectrometer (ICP-MS, Agilent 7500ce, Japan). The metal-contained metallogels were cut into round discs with a diameter of $15 \mathrm{~mm}$ and thickness of $1.5 \mathrm{~mm}$. The metallogel disc was immersed into $5 \mathrm{~mL}$ of PBS buffer at $\mathrm{pH}$ of 7.4 at $37^{\circ} \mathrm{C}$ with agitation at $30 \mathrm{rpm}$. At each time point, the solution was collected for measuring the accumulative release of metal ions. $5 \mathrm{~mL}$ of fresh PBS buffer has added to compensate for replacing solutions.

pH- and $\mathrm{H}_{2} \mathrm{O}_{2}$-responsiveness of metallogels. The $\mathrm{pH}$ - and $\mathrm{H}_{2} \mathrm{O}_{2}$-responsiveness of $\mathrm{TA}-\mathrm{Ti}^{\mathrm{IV}}$ - $\mathrm{Cu}^{\mathrm{II}}$ metallogels were characterized by measuring the amount of released $\mathrm{Cu}^{\mathrm{II}}$. The released $\mathrm{Cu}^{\mathrm{II}}$ was quantified at incubation time points of 12,24 and $36 \mathrm{~h}$ by ICP-MASS. The TA-Ti ${ }^{\mathrm{IV}}-\mathrm{Cu}^{\mathrm{II}}$ metallogels were cut into round discs with a diameter of $15 \mathrm{~mm}$ and thickness of $1.5 \mathrm{~mm}$. For the $\mathrm{pH}$-responsiveness, the metallogels, buffered solutions at $\mathrm{pH}$ values of $5.5,7.4$ and 8.4 were prepared. The TA- $\mathrm{Ti}^{\mathrm{IV}}-\mathrm{Cu}^{\mathrm{II}}$ metallogels were immersed in $5 \mathrm{~mL}$ of buffered solutions at $37^{\circ} \mathrm{C}$ with agitation at $30 \mathrm{rpm}$. At every 12 -h period of time, the concentration of $\mathrm{Cu}^{\mathrm{II}}$ in the solution was measured using the assay kit. Afterward, fresh $5 \mathrm{~mL}$ of the buffered solution was added for the next measurement.

For the $\mathrm{H}_{2} \mathrm{O}_{2}$ responsiveness test, the concentration of $\mathrm{Cu}^{\mathrm{II}}$ in ppm, released from $\mathrm{TA}-\mathrm{Ti}^{\mathrm{iV}}-\mathrm{Cu}^{\mathrm{II}}$ metallogels, was determined after incubation with $\mathrm{H}_{2} \mathrm{O}_{2}$ in a buffer at $\mathrm{pH} 5.5$ at $37^{\circ} \mathrm{C}$ for $36 \mathrm{~h}$. To further confirm the $\mathrm{H}_{2} \mathrm{O}_{2}$ responsiveness of metallogels, $\mathrm{HRP}$, that catalyzes the oxidation of various organic substrates by $\mathrm{H}_{2} \mathrm{O}_{2}$, was included in the metallogels to observe the release of $\mathrm{Cu}^{\mathrm{II}}$. For the HRP encapsulation, HRP in PBS was introduced to mix with the TA solution to achieve the final concentration in each gel is $62.5 \mathrm{U} / \mathrm{gel}$ and $31.5 \mathrm{U} /$ gel. The size of the metallogels was described as above, which is a round disc with a diameter of $15 \mathrm{~mm}$ and thickness of $1.5 \mathrm{~mm}$. After mixture, $\mathrm{Ti}^{\mathrm{IV}}$ and $\mathrm{Cu}^{\mathrm{II}}$ were added and vortexed for $10 \mathrm{~s}$. The metallogels containing HRP (TA-Ti ${ }^{\mathrm{IV}}-\mathrm{Cu}^{\mathrm{II}}-\mathrm{HRP}$ ) were formed after $20 \mathrm{~min}$. The test for the release of $\mathrm{Cu}^{\mathrm{II}}$ in the presence of $\mathrm{H}_{2} \mathrm{O}_{2}$ was determined at $\mathrm{pH} 5.5$ at $37^{\circ} \mathrm{C}$ for $36 \mathrm{~h}$.

Minimum inhibitory concentrations (MICs) of metal ions. MIC is the concentrations at which an antibacterial agent experiences the complete inhibitions of the growth of microorganisms ${ }^{22}$. The MICs of metal ions were determined using the microbroth dilution method in a 96-well plate for the three bacteria (E. coli, S. aureus and S. epidermidis). E. coli was grown overnight in LB media, and S. aureus and S. epidermidis were grown overnight in TSB media. The bacterial solutions were diluted to an optical density of 0.1 at $670 \mathrm{~nm}$ (OD670) in corresponding medium. Consequently, $100 \mu \mathrm{L}$ of the bacterial solutions were distributed to each well of the 96-well plate. The concentrations of metal ions were prepared, ranging from $0.125 \mu \mathrm{M}$ to $32 \mu \mathrm{M}$. The bacterial solutions in wells were incubated with metal ions for $10 \mathrm{~h}$, followed by measuring the OD670 values of the testing solutions by microplate reader (Synergy 2 Multi-Mode, BioTek, USA). The growth curves of bacteria in metal ion solutions were shown in Supplementary Information (Figs S1-S3).

Cytotoxicity of metal ions. The cytotoxicity of metal ions for NIH 3T3 fibroblast cells was evaluated by MTT assay. The concentrations of metal ion solutions were prepared ranging from $31.25 \mu \mathrm{M}$ to $250 \mu \mathrm{M}$. 3T3 fibroblasts cells were cultured in a 24 -well plate at a seeding concentration of $1 \times 10^{4}$ cell/well in DMEM containing $10 \%$ of $\mathrm{FBS}$ in a humidified $5 \% \mathrm{CO}_{2}$ incubator at $37^{\circ} \mathrm{C}$ for $24 \mathrm{~h}$. Afterward, the culture medium was replaced by FBS-free DMEM, which contained metal ions of interest at various concentrations. After incubation for $24 \mathrm{~h}$, the MTT solution was introduced to the culture medium to a final concentration of $0.5 \mathrm{mg} / \mathrm{mL}$. MTT, a yellow tetrazole, is reduced to purple formazan in living cells. Therefore, after incubations for $3 \mathrm{~h}$, the medium was replaced by DMSO in each well to dissolve the purple formazan crystals. The absorbance of solutions was quantified by a spectroscopic reader at $550 \mathrm{~nm}$. The cell culture without treatment was set as a control. The resulting value was averaged from triplicate samples.

Tests for zone of inhibition. Antibacterial activity of metallogels was accessed by disc diffusion test by measurement of zone of inhibition. E. coli was cultured in sterile LB liquid culture medium; S. epidermidis and USA300 were incubated in sterile TSB at $37^{\circ} \mathrm{C}$ for $24 \mathrm{~h}$. Then, the bacterial solutions were diluted to 0.1 of OD670 using the corresponding medium, followed by dropping $10 \mu \mathrm{L}$ of diluted bacterial solutions onto sterile agar plates and spreading homogeneously. Six samples of metallogels, $\mathrm{TA}-\mathrm{Ti}^{\mathrm{IV}}, \mathrm{TA}-\mathrm{Ti}^{\mathrm{IV}}-\mathrm{Fe}^{\mathrm{III}}, \mathrm{TA}-\mathrm{Ti}^{\mathrm{IV}}-\mathrm{Cu}^{\mathrm{II}}, \mathrm{TA}-\mathrm{Ti}^{\mathrm{IV}}-\mathrm{Co}^{\mathrm{II}}$, $\mathrm{TA}-\mathrm{Ti}^{\mathrm{IV}}-\mathrm{Ni}^{\mathrm{II}}$, and $\mathrm{TA}-\mathrm{Ti}^{\mathrm{IV}}-\mathrm{Zn}^{\mathrm{II}}$ were cut into a round shape with a diameter of $8 \mathrm{~mm}$ and thickness of $1.5 \mathrm{~mm}$. The samples were placed on the agar plates in an incubator for $24 \mathrm{~h}$. The zone of inhibition is measured using a pair of calipers. Its size is rounded off to the closest millimeter, and the diameter of the disk is also included.

Animal tests. This study was carried out in strict accordance with an approved Institutional Animal Care and Use Committee (IACUC) protocol at National Central University (NCU), Taiwan. The experimental animals and were purchased from BioLASCO Taiwan Co., Ltd. The animal experiments were conducted referring to previous work ${ }^{23}$. Six female mice weighed 250-300 g were used in this study. Animals were anesthetized via injection of 2,2,2-tribromoethanol. Dorsal skin was shaved and sanitized. A circular full-thickness wound was created by a punch with a $6 \mathrm{~mm}$ diameter. $10 \mu \mathrm{L}$ of pathogenic $S$. aureus bacterial solution at a concentration of $10^{7} \mathrm{CFU} / \mathrm{mL}$ in PBS was dropped on the wounds. Three dressings, including gauze, $\mathrm{TA}-\mathrm{Ti}^{\mathrm{IV}}$ and $\mathrm{TA}-\mathrm{Ti}^{\mathrm{IV}}-\mathrm{Cu}^{\mathrm{II}}$ 

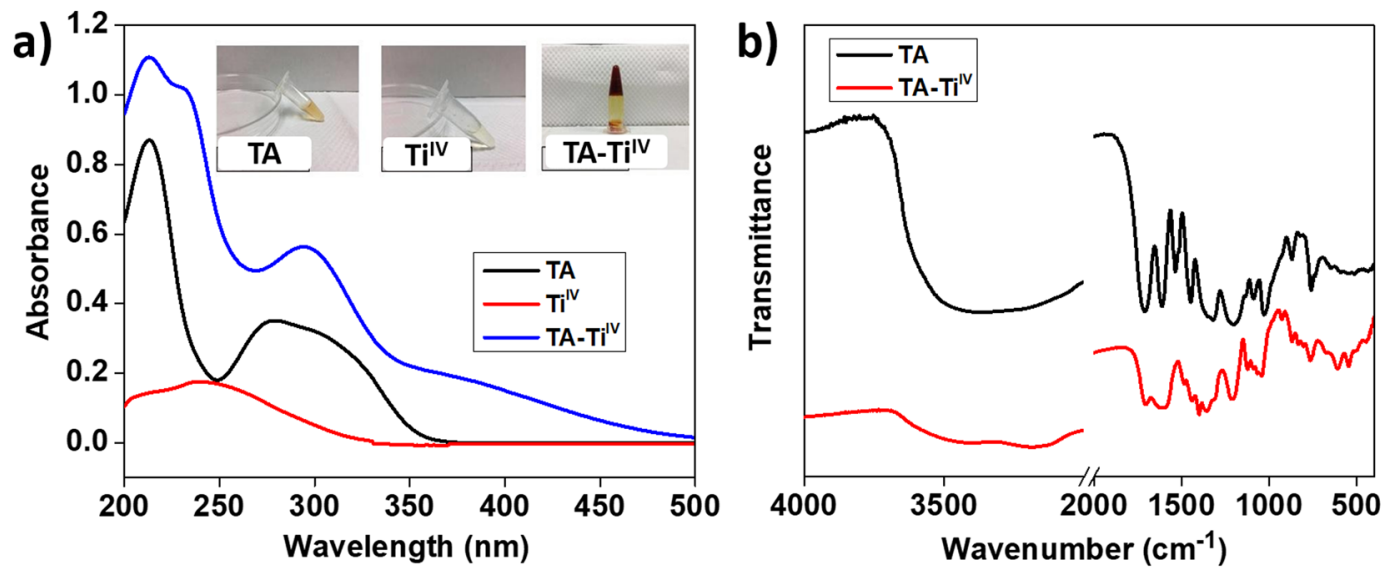

Figure 1. Characterizations of the formation of $\mathrm{TA}-\mathrm{Ti}^{\mathrm{IV}}$ metallogels using $\mathrm{UV}$-vis (a) and FTIR (b) spectroscopies. The inserted photographs in (a) indicate the solutions of $\mathrm{TA}, \mathrm{Ti}^{\mathrm{IV}}$, and $\mathrm{TA}-\mathrm{Ti}^{\mathrm{IV}}$ in tubes.

metallogels were placed on the wounds, followed by covering Tegaderm ( $3 \mathrm{M}$, USA) to immobilize the dressings. Dressings were changed on day 1 , day 4 , and day 6 . The appearance of wounds was observed and photographed. The analytical equations of the percentage of the wound area were based on the ratio of recovered wound area and created wound area on day 0 . The animal experiments completed when wounds with one type of dressing were apparently healed. Animals were euthanized at the endpoint of day 8 . In addition, the concentrations of $S$. aureus on infected wounds with treatment of $\mathrm{TA}-\mathrm{Ti}^{\mathrm{IV}}$, and $\mathrm{TA}-\mathrm{Ti}^{\mathrm{IV}}-\mathrm{Cu}^{\mathrm{II}}$ were determined on 8 day. The cotton stick was used to collect bacteria on wounds and put into $1 \mathrm{~mL}$ PBS solution, followed by bacterial culture on TSB agar supplemented with $1 \%$ methicillin and incubation at $35^{\circ} \mathrm{C}$ for $24 \mathrm{~h}$. Afterward, the colony forming unit (CFU) on agar was calculated.

Statistical analysis. Values are expressed as means \pm standard deviation (S.D.) unless otherwise indicated. Student's t-test was used for comparisons of data to assess significant differences.

\section{Results and Discussion}

Formation of metallogels. $\mathrm{TA}$ and $\mathrm{Ti}^{\mathrm{IV}}$ were mixed at $\mathrm{pH} 7$ for the formation of $\mathrm{TA}-\mathrm{Ti}^{\mathrm{IV}}$ metallogels. UV-vis and FTIR spectroscopies were employed to characterize coordinative interactions of the metal ions and phenolic groups. In Fig. 1a, the UV-Vis spectrum of the TA solution presents two absorbance peaks at 213 and $279 \mathrm{~nm}$. The $\mathrm{Ti}^{\mathrm{IV}}$ solution shows a broad band in the range $225-275 \mathrm{~nm}$ with a maximum at $239 \mathrm{~nm}$. After adding the $\mathrm{Ti}^{\mathrm{IV}}$ solution in the TA solution, an increasing in absorbance in a range of $375-450 \mathrm{~nm}$, corresponding to coordinative interaction. The results are consistent with the previous literature ${ }^{14}$, indicating the formation of bis/ tris-type chelating structures ${ }^{24}$. TA provides multiple galloyl chelating sites, which can coordinate with various transition metals. The stable coordination structure between $\mathrm{TA}$ and $\mathrm{Ti}^{\mathrm{IV}}$ can be explained by high oxidation state and formal charge of $\mathrm{Ti}^{\mathrm{IV}}$, which plays a significant role in the solvent-trapping process of the gelation. Moreover, the inserted photographs in Fig. 1a display appearance of $\mathrm{TA}, \mathrm{Ti}^{\mathrm{IV}}$ solutions and the $\mathrm{TA}-\mathrm{Ti}^{\mathrm{IV}}$ metallogel. The gel was formed after mixing for $15 \mathrm{~min}$ and the color of solutions turned to red, reflecting the absorbance at high wavelength from the UV-vis spectroscopic measurements.

Additionally, the interactions between $\mathrm{TA}$ and $\mathrm{Ti}^{\mathrm{IV}}$ in metallogels were investigated by FTIR spectroscopy (Fig. 1b). The FTIR spectrum of TA shows a characteristic peak at $3369 \mathrm{~cm}^{-1}$ for stretching vibration of $\mathrm{H}$-bonded $-\mathrm{OH}^{25}$, and a peak at $1711 \mathrm{~cm}^{-1}$ for stretching vibration of $\mathrm{C}=\mathrm{O}$ (carboxylic ester) groups ${ }^{26}$, and a peak at 1612 $\mathrm{cm}^{-1}$ for aromatic $\mathrm{C}=\mathrm{C}$ in free phenolic groups ${ }^{27}$. Moreover, peaks at 1535 and $1447 \mathrm{~cm}^{-1}$ were attributed to vibrations of aromatic C-C stretching ${ }^{25}$. Peaks at 1320 and $1202 \mathrm{~cm}^{-1}$ correspond to $\mathrm{O}-\mathrm{H}$ deformation of phenolic, and a peak at $758 \mathrm{~cm}^{-1}$ was represented for vibration of aromatic $\mathrm{C}-\mathrm{H}^{4,16}$. The shifts of the characteristic peaks for $\mathrm{TA}-\mathrm{Ti}^{\mathrm{IV}}$ metallogels with respect to the $\mathrm{TA}$ alone have been proven by the disappearance of the $\mathrm{H}$-bonded $-\mathrm{OH}$ and manifested by a broadened peak at $3182 \mathrm{~cm}^{-1}$ due to the formation the coordinative bonding between $-\mathrm{OH}$ and $\mathrm{Ti}^{\mathrm{IV}}$. Moreover, the peaks for the stretching of aromatic $\mathrm{C}-\mathrm{C}$ in TA shifted to 1484 and $1439 \mathrm{~cm}^{-1}$ due to deprotonations of the hydroxyl groups and complexation with metal ions. In addition, the coordinative interaction attributed to the shifts of the vibrations of $\mathrm{O}-\mathrm{H}$ bonds to 1400,1216 , and $764 \mathrm{~cm}^{-14,25}$. Consequently, the formation of metallogels through the chelation of phenolic groups in $\mathrm{TA}$ and $\mathrm{Ti}^{\mathrm{IV}}$ was demonstrated by spectroscopic analysis.

Release profiles of antimicrobial metal ions from metallogels. Antimicrobial metal ions of $\mathrm{Fe}^{\mathrm{III}}$, $\mathrm{Cu}^{\mathrm{II}}, \mathrm{Co}^{\mathrm{II}}, \mathrm{Ni}^{\mathrm{II}}$, and $\mathrm{Zn}^{\mathrm{II}}$ were incorporated into the metallogels. The release profiles of the metal ions were recorded by using ICP-MASS to determine the difference in the coordination strength with phenolic groups of TA (Fig. 2). The metallogels of TA-Ti ${ }^{\mathrm{IV}}-\mathrm{Fe}^{\mathrm{III}}, \mathrm{TA}-\mathrm{Ti}^{\mathrm{IV}}-\mathrm{Cu}^{\mathrm{II}}, \mathrm{TA}-\mathrm{Ti}^{\mathrm{IV}}-\mathrm{Co}^{\mathrm{II}}, \mathrm{TA}-\mathrm{Ti}^{\mathrm{IV}}-\mathrm{Ni}^{\mathrm{II}}$, and $\mathrm{TA}-\mathrm{Ti}^{\mathrm{IV}}-\mathrm{Zn}^{\mathrm{II}}$ were immersed into $\mathrm{PBS}$ at $\mathrm{pH} 7.4$ and physiological temperature of $37^{\circ} \mathrm{C}$. As shown in Fig. 2, $\mathrm{Ni}^{\mathrm{II}}$ was released from $\mathrm{TA}-\mathrm{Ti}^{\mathrm{IV}}-\mathrm{Ni}^{\mathrm{II}}$ fastest, followed by $\mathrm{Co}^{\mathrm{II}}, \mathrm{Zn}^{\mathrm{II}}, \mathrm{Cu}^{\mathrm{II}}$, and $\mathrm{Fe}^{\mathrm{III}}$. The release profiles of metals from metallogels were fitted using Higuchi model ${ }^{28}$ : 


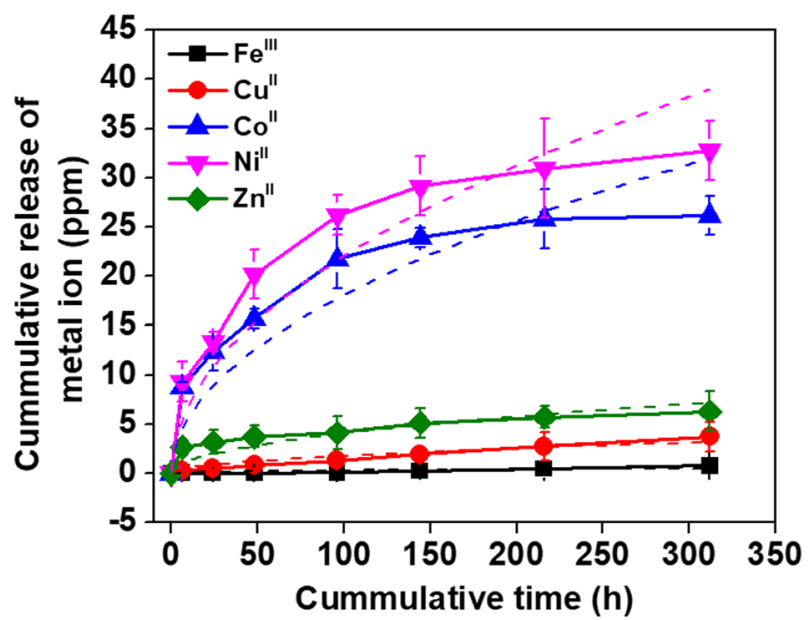

Figure 2. The release profiles of metal ions from metallogels in $\mathrm{PBS}$ at $\mathrm{pH} 7.4$ and $37^{\circ} \mathrm{C}$. The cumulative release concentrations of metal ions were recorded using ICP-MASS for 13 days. The data was fitted by using the Higuchi model (dash lines).

\section{a)}

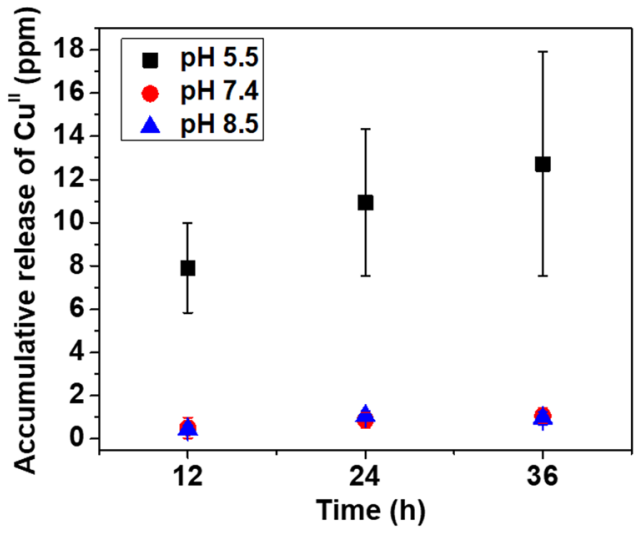

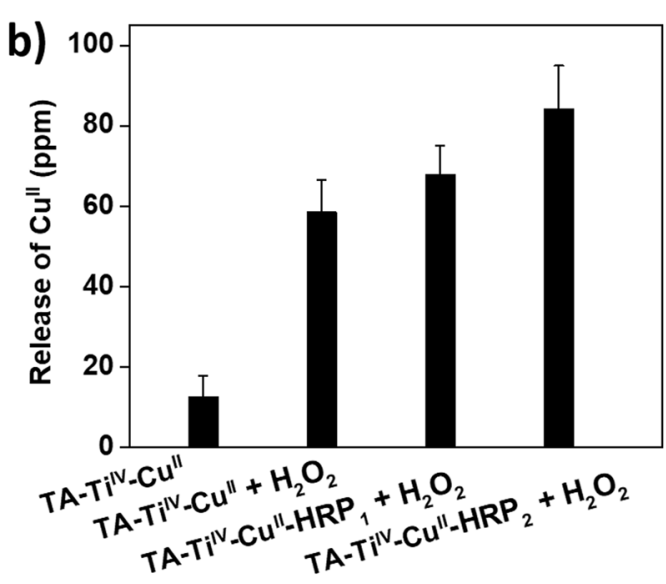

Figure 3. The release of $\mathrm{Cu}^{\mathrm{II}}$ from metallogels in responses to the changes in $\mathrm{pH}(\mathbf{a})$ and the presence of $\mathrm{H}_{2} \mathrm{O}_{2}$ at pH 5.5 (b).

$$
\mathrm{Q}=K_{H} \times t^{1 / 2}
$$

where $\mathrm{Q}$ is cumulative release amount, $\mathrm{t}$ is the release time in hour, and $\mathrm{K}_{\mathrm{H}}$ is the Higuchi dissolution constant. In this work, the $\mathrm{K}_{\mathrm{H}}$ values for $\mathrm{Fe}^{\mathrm{III}}, \mathrm{Cu}^{\mathrm{II}}, \mathrm{Co}^{\mathrm{II}}, \mathrm{Ni}^{\mathrm{II}}$, and $\mathrm{Zn}^{\mathrm{II}}$ were $0.03,0.18,1.81,2.20$, and 0.41 , respectively. Therefore, the $\mathrm{K}_{\mathrm{H}}$ values reflect the release order. The different release profiles of metal ions can be explained by the strength of coordinative interaction with phenolic groups. According to empirical hard-soft acid-base theory $(\mathrm{HSAB})^{17}$, acidic phenolic components, such as TA, have a pKa value in the range of $7-9$, thus they are easily deprotonated at or below physiological $\mathrm{pH}$. Deprotonated polyphenol ligands behave as hard Lewis bases, giving rise to large metal-binding constants with hard Lewis acids, such as $\mathrm{Ti}^{\mathrm{IV}}$ and $\mathrm{Fe}^{\mathrm{III}}$. In contrast, $\mathrm{Cu}^{\mathrm{II}}, \mathrm{Zn}^{\mathrm{II}}, \mathrm{Ni}^{\mathrm{II}}$ and $\mathrm{Co}^{\mathrm{II}}$ are moderate Lewis acids and do not bind as strongly as hard Lewis acid to hard oxygen atoms of phenolic groups. Moreover, previous study indicated $\mathrm{Cu}^{\mathrm{II}}$ has a higher binding constant with phenolic groups than $\mathrm{Zn}^{\mathrm{II}}{ }^{29}$, which is consistent with higher $\mathrm{Zn}^{\mathrm{II}}$ release rate than $\mathrm{Cu}^{\mathrm{II}}$ from $\mathrm{TA}-\mathrm{Ti}^{\mathrm{IV}}$ metallogels. It is worthwhile to note that undetectable release of $\mathrm{Ti}^{\mathrm{IV}}$ was found from the ICP-MASS detection, thereby the structure of the metallogels was maintained throughout the testing period.

Triggered release of metal ions from metallogels. The susceptibility of the coordinative structures between TA and metal ions to $\mathrm{pH}$ and $\mathrm{H}_{2} \mathrm{O}_{2}$ was investigated to explore responsiveness of the metallogels. In Fig. 3a, three different $\mathrm{pH}$ values have been used to test the release profiles of $\mathrm{Cu}^{\mathrm{II}}$ from metallogels of $\mathrm{TA}-\mathrm{Ti}^{\mathrm{IV}}-\mathrm{Cu}^{\mathrm{II}}$. As a result, the release of $\mathrm{Cu}^{\mathrm{II}}$ at $\mathrm{pH} 5.5$ was much faster than that higher $\mathrm{pH}$, indicating the disassembly of the phenol-metal coordinative structure ${ }^{14}$. At a low $\mathrm{pH}$ value, the galloyl groups of TA are predominately protonated and relatively few phenolate binding sites are available for complexations with $\mathrm{Cu}^{\mathrm{II}}$, facilitating 

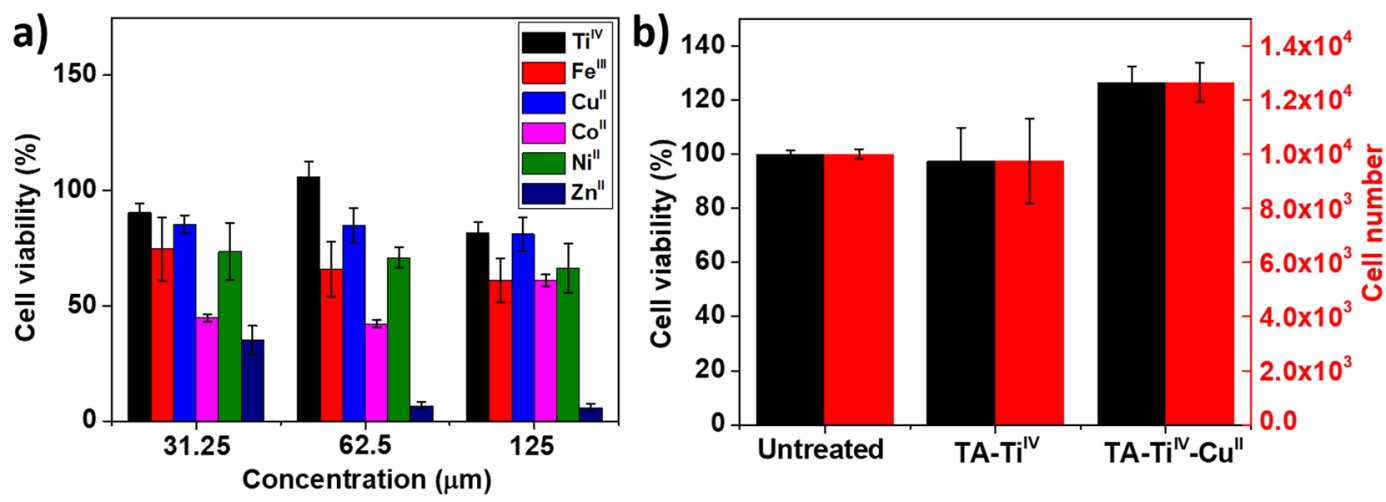

Figure 4. MTT assays for metal ions in solutions (a) and metallogels (b). NIH-3T3 fibroblasts were used for the MTT assays.

\begin{tabular}{|c|c|c|c|}
\hline \multicolumn{4}{|c|}{$\operatorname{MIC}(\mathbf{m M})$} \\
\hline & E. coli & S. aureus & S. epidermidis \\
\hline $\mathrm{Ti}^{\mathrm{IV}}$ & - & - & - \\
\hline $\mathrm{Fe}^{\mathrm{III}}$ & $4 \pm 0.5$ & $8 \pm 0.5$ & $8 \pm 0.4$ \\
\hline $\mathrm{Cu}^{\mathrm{II}}$ & $4 \pm 0.3$ & $8 \pm 0.7$ & $8 \pm 1.1$ \\
\hline $\mathrm{Co}^{\mathrm{II}}$ & $0.5 \pm 0.2$ & $1 \pm 0.3$ & $2 \pm 0.2$ \\
\hline $\mathrm{Ni}^{\mathrm{II}}$ & $2 \pm 0.2$ & $4 \pm 0.6$ & $4 \pm 0.2$ \\
\hline $\mathrm{Zn}^{\mathrm{II}}$ & $1 \pm 0.3$ & $16 \pm 2.2$ & $16 \pm 1.5$ \\
\hline
\end{tabular}

Table 1. MIC tests for metal ions with E. coli, S. aureus and S. epidermidis.

the high accumulative concentration. On the contrary, at the high $\mathrm{pH}$, the number of deprotonated phenolate groups increases for complexation with $\mathrm{Cu}^{\mathrm{II}}$.

The release of $\mathrm{Cu}^{\mathrm{II}}$ from TA- $\mathrm{Ti}^{\mathrm{IV}}-\mathrm{Cu}^{\mathrm{II}}$ in the presence of oxidizer of $\mathrm{H}_{2} \mathrm{O}_{2}$ was measured in Fig. 3b. The concentration of released $\mathrm{Cu}^{\mathrm{II}}$ from metallogels in $\mathrm{H}_{2} \mathrm{O}_{2}$ was 4 .1-fold higher than that without $\mathrm{H}_{2} \mathrm{O}_{2}$. Moreover, the $\mathrm{TA}-\mathrm{Ti}^{\mathrm{IV}}-\mathrm{Cu}^{\mathrm{II}}$ metallogels were incorporated with $\mathrm{HRP}$ enzymes with a concentration of 31 and $62 \mathrm{U} /$ gel, corresponding to $\mathrm{TA}-\mathrm{Ti}^{\mathrm{IV}}-\mathrm{Cu}^{\mathrm{II}}-\mathrm{HRP}_{1}$ and $\mathrm{TA}-\mathrm{Ti}^{\mathrm{IV}}-\mathrm{Cu}^{\mathrm{II}}-\mathrm{HRP}_{2}$, respectively. HRP catalyzes the oxidation of various organic substrates by $\mathrm{H}_{2} \mathrm{O}_{2}$. Thus, we suspect that the release of $\mathrm{Cu}^{\mathrm{II}}$ should be accelerated in the presence of HRP and $\mathrm{H}_{2} \mathrm{O}_{2}$ in the metallogels. The faster release of $\mathrm{Cu}^{\mathrm{II}}$ from the metallogels associated with the concentration of HRP was observed, and, however, the changes were not dramatic. Therefore, in consideration of cost effectiveness and ease of preparation, the metallgels without HRP were employed for biological tests and applications.

The increased release of $\mathrm{Cu}^{\mathrm{II}}$ from the metallogels triggered by $\mathrm{H}_{2} \mathrm{O}_{2}$ is ascribed to two mechanisms: 1 . the oxidation of phenols to quinones in TA, leading to loss of coordinative capability with $\mathrm{Cu}^{\mathrm{II} 30} ; 2$. the formation of $\mathrm{Cu}^{\mathrm{I}}$ in the presence of $\mathrm{H}_{2} \mathrm{O}_{2}$ due to the Fenton-like reaction ${ }^{31}$. For the antibacterial property, the redox of $\mathrm{Cu}^{\mathrm{II}}$ is majorly responsible for killing bacteria through damaging the outer membrane and inhibiting cell respiration by producing a high level of $\mathrm{ROS}^{32}$. $\mathrm{Cu}^{\mathrm{II}}$ was also found to interfere with the replication of $16 \mathrm{~S}$ rRNA genes ${ }^{33}$. In addition, $\mathrm{Cu}^{\mathrm{I}}$ can directly react with certain metabolic enzymes in bacteria and deactivate them ${ }^{34}$. Taken together, the results have further strengthened hypothesis of the enhanced antimicrobial property of $\mathrm{TA}-\mathrm{Ti}^{\mathrm{IV}}-\mathrm{Cu}^{\mathrm{II}}$ in the presence of $\mathrm{H}^{+}$and $\mathrm{H}_{2} \mathrm{O}_{2}$, which endogenously generate in the infected wounds.

Cytotoxicity test of metallogels. The cytotoxicity of metal ions in solutions was investigated with NIH-3T3 fibroblasts. As shown in Fig. 4a, the concentrations of metal ions were prepared in a range from 31.25 to $125 \mu \mathrm{M}$ and the solutions were incubated with fibroblasts in a serum-free DMEM for $24 \mathrm{~h}$, followed by the MTT assay. As a result, $\mathrm{Co}^{\mathrm{II}}$ and $\mathrm{Zn}^{\mathrm{II}}$ displayed high toxicity to fibroblasts, and $\mathrm{Ti}^{\mathrm{IV}}$ and $\mathrm{Cu}^{\mathrm{II}}$ exhibited negligible toxicity in the range of the concentrations. Moreover, cytotoxicity of the metallogels of TA-Ti ${ }^{\mathrm{IV}}$ and $\mathrm{TA}-\mathrm{Ti}^{\mathrm{IV}}-\mathrm{Cu}^{\mathrm{II}}$ were accessed in Fig. $4 \mathrm{~b}$. Obviously, the growth of fibroblasts was not affected by the metallogels, likely due to low cytotoxicity of natural product of $\mathrm{TA}$ and slow release of $\mathrm{Cu}^{\mathrm{II}}$ and $\mathrm{Ti}^{\mathrm{IV}}$. The high cell viability for all samples reveals the low cytotoxicity of the metallogels for medical applications.

Antimicrobial properties of metallogels. MIC tests were conducted for evaluating the antimicrobial capability of all metal ions in solutions. Three bacteria, Gram-negative E. coli, Gram-positive S. aureus, and S. epidermidis, which are common cause of infections involving indwelling foreign devices and surgical wound infections, were employed. In Table 1, E. coli seems susceptible to metal ions, likely reflecting their different degrees of interaction with cell wall structures. Generally, different metals cause distinct types of damages to microbial cells as a result of oxidative stress, protein dysfunction, membrane damage and genotoxicity. $\mathrm{Co}^{\mathrm{II}}$ was more toxic to bacteria than others. The antimicrobial capabilities of $\mathrm{Fe}^{\mathrm{III}}$ and $\mathrm{Cu}^{\mathrm{II}}$ metal ions were comparable and moderate. 

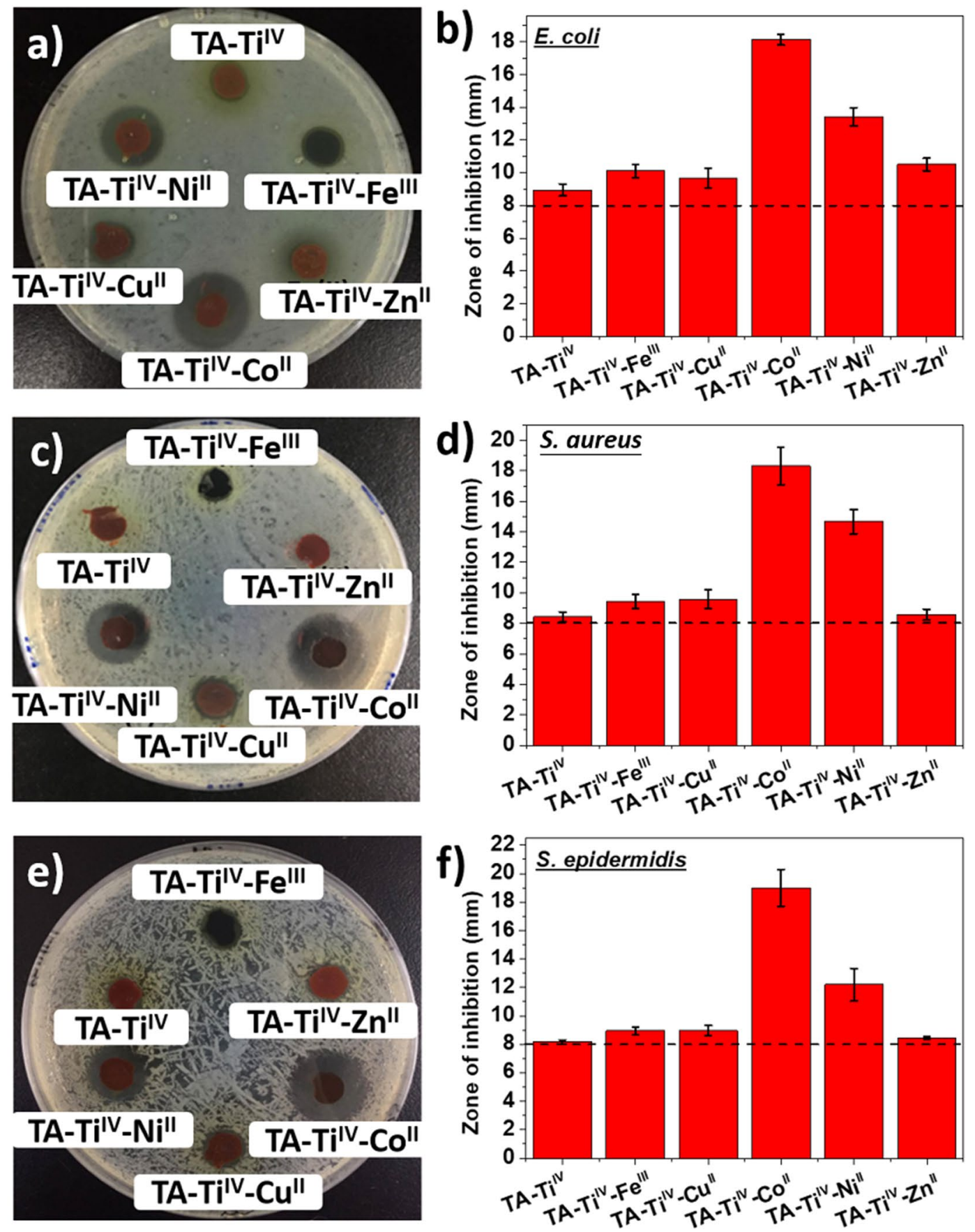

Figure 5. The disc diffusion tests for metallogels of $\mathrm{TA}-\mathrm{Ti}{ }^{\mathrm{IV}}, \mathrm{TA}-\mathrm{Ti}^{\mathrm{IV}}-\mathrm{Fe}^{\mathrm{III}}, \mathrm{TA}-\mathrm{Ti}^{\mathrm{IV}}-\mathrm{Cu}^{\mathrm{II}}, \mathrm{TA}-\mathrm{Ti}^{\mathrm{IV}}-\mathrm{Co}^{\mathrm{II}}, \mathrm{TA}-\mathrm{Ti}^{\mathrm{IV}}-$ $\mathrm{Ni}^{\mathrm{II}}$, and $\mathrm{TA}-\mathrm{Ti}^{\mathrm{IV}}-\mathrm{Zn}^{\mathrm{II}}$ with E. coli $(\mathbf{a}, \mathbf{b})$, S. aureus $(\mathbf{c}, \mathbf{d})$ and $S$. epidermidis $(\mathbf{e}, \mathbf{f})$. The dashed lines indicate the original diameter of the metallogel discs.

The disc diffusion tests were carried out for the metallogels to compare their antimicrobial properties by measuring the diameter of the inhibition zone in Fig. 5. E. coli (Fig. 5a,b), S. aureus (Fig. 5c,d) and S. epidermidis (Fig. 5e,f) were spread and cultured on agar plates, followed by incubation with metallogels for $24 \mathrm{~h}$. From the diameter measurements of Fig. 5b,d and f, the dashed lines indicate the original diameter of the metallogel discs, which is $8 \mathrm{~mm}$. Therefore, TA-Ti ${ }^{\mathrm{IV}}$ showed a marginal effectiveness to suppress the growth of bacteria. Moreover, the data from the inhibition zones of $\mathrm{TA}-\mathrm{Ti}^{\mathrm{IV}}-\mathrm{Zn}^{\mathrm{II}}$ are in agreement with that from MIC tests, showing high toxicity to E. coli, but not to $S$. aureus and S. epidermidis. Moreover, $\mathrm{TA}-\mathrm{Ti}^{\mathrm{IV}}-\mathrm{Co}^{\mathrm{II}}$ exhibited the strongest antimicrobial property against all bacteria, followed by $\mathrm{TA}-\mathrm{Ti}^{\mathrm{iV}}-\mathrm{Ni}^{\mathrm{II}}$. The results can be ascribed to high antimicrobial potency (Table 1) and fast release of $\mathrm{Co}^{\mathrm{II}}$ and $\mathrm{Ni}^{\mathrm{II}}$ (Fig. 2) from the metallogels. Although the excellent antimicrobial performance with $\mathrm{Co}^{\mathrm{II}}$ and $\mathrm{Ni}^{\mathrm{II}}$ was observed, the high cytotoxicity and fast release from the metallogels constrain medical applications. On the contrary, $\mathrm{TA}-\mathrm{Ti}^{\mathrm{IV}}-\mathrm{Cu}^{\mathrm{II}}$ did not appear to effectively kill bacteria. The good biocompatibility and controlled release of $\mathrm{Cu}^{\mathrm{II}}$ make $\mathrm{TA}-\mathrm{Ti}^{\mathrm{IV}}-\mathrm{Cu}^{\mathrm{II}}$ a suitable material for medical uses. 

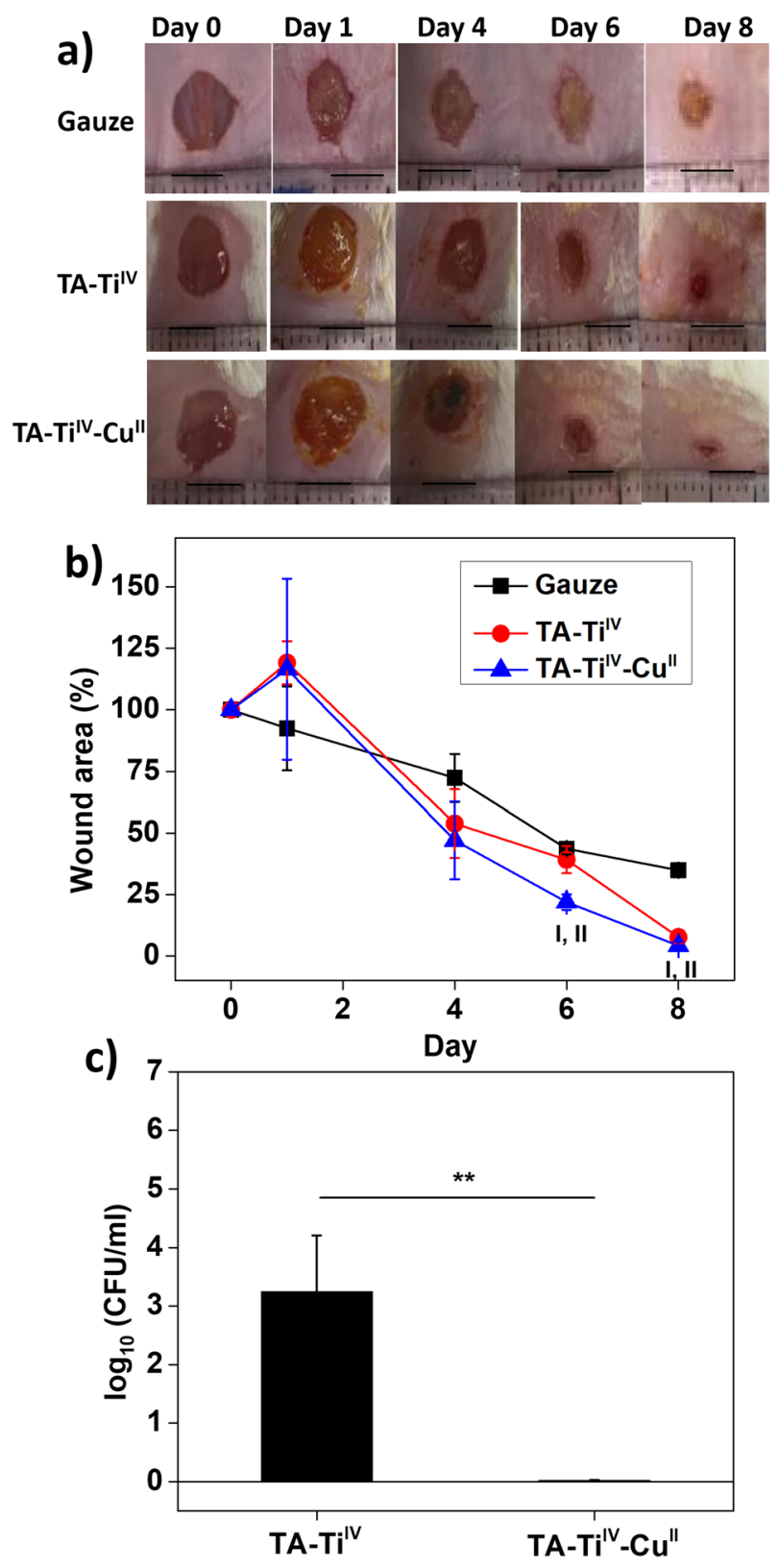

Figure 6. Animal tests for wound dressings for healing of infected wounds. The photographs of wounds with treatment of dressings of gauze, $\mathrm{TA}-\mathrm{Ti}^{\mathrm{IV}}$, and $\mathrm{TA}-\mathrm{Ti}^{\mathrm{IV}}-\mathrm{Cu}^{\mathrm{II}}(\mathbf{a})$. Scare bars: $5 \mathrm{~mm}, \mathrm{n}=3$. The wound areas for the wounds with different dressings $(\mathbf{b})$. I: significant difference between gauze and $\mathrm{TA}-\mathrm{Ti}^{\mathrm{IV}}-\mathrm{Cu}^{\mathrm{II}}(\mathrm{p}<0.05)$. II: significant difference between $\mathrm{TA}-\mathrm{Ti}^{\mathrm{IV}}$ and $\mathrm{TA}-\mathrm{Ti}^{\mathrm{IV}}-\mathrm{Cu}^{\mathrm{II}}(\mathrm{p}<0.05)$. Bacterial concentrations of infected wounds with treatment of $\mathrm{TA}-\mathrm{Ti}^{\mathrm{IV}}$, and $\mathrm{TA}-\mathrm{Ti}^{\mathrm{IV}}-\mathrm{Cu}^{\mathrm{II}}$ for 8 days $(\mathbf{c}) . * * \mathrm{p}<0.01$.

Consequently, $\mathrm{TA}-\mathrm{Ti}^{\mathrm{IV}}-\mathrm{Cu}^{\mathrm{II}}$ metallogel was employed as a smart dressing for controlled release antimicrobial metal ions in response to the changes in $\mathrm{pH}$ and the presence of $\mathrm{H}_{2} \mathrm{O}_{2}$. Herein, the responsiveness of TA- $\mathrm{Ti}^{\mathrm{IV}}-\mathrm{Cu}^{\mathrm{II}}$ cannot be performed by the disc diffusion test because acid and $\mathrm{H}_{2} \mathrm{O}_{2}$ are bactericidal agents. The test cannot distinguish the antimicrobial roles of metal ions, acid and $\mathrm{H}_{2} \mathrm{O}_{2}$. Accordingly, the antimicrobial and responsiveness of $\mathrm{TA}-\mathrm{Ti}^{\mathrm{IV}}-\mathrm{Cu}^{\mathrm{II}}$ will be demonstrated on infected wounds in mice.

Metallogels as infected wound dressings. The use of $\mathrm{TA}-\mathrm{Ti}^{\mathrm{IV}}-\mathrm{Cu}^{\mathrm{II}}$ as a dressing material for infected wounds was conducted to demonstrate the unique characteristics of metallogels. The wounds were created on the back of mice and applied with pathogenic $S$. aureus. Gauze and $\mathrm{TA}-\mathrm{Ti}^{\mathrm{IV}}$ were employed as dressings for comparison. In Fig. 6a, the photographs of wounds with treatment of different dressings were taken periodically to estimate their wound areas. In Fig. 6b, the healing rates of the wounds were determined by reduction in the wound areas. As a result, the wounds with $\mathrm{TA}-\mathrm{Ti}^{\mathrm{IV}}-\mathrm{Cu}^{\mathrm{II}}$ displayed faster recovery than that with other dressings. Moreover, the presence of bacteria on wounds was estimated by counting CFU on tryptic soy broth (TSB) agar supplemented with $1 \%$ methicillin. The cotton stick was used to collect bacteria on wounds and put into $1 \mathrm{~mL}$ PBS 
solution, followed by bacterial culture on agar plates to calculate colony forming unit (CFU). In Fig. 6c, obviously, the concentration of bacteria on the wounds with $\mathrm{TA}-\mathrm{Ti}^{\mathrm{IV}}-\mathrm{Cu}^{\mathrm{II}}$ was extremely lower than that with $\mathrm{TA}-\mathrm{Ti}^{\mathrm{IV}}$, showing good antimicrobial potency of $\mathrm{TA}-\mathrm{Ti}^{\mathrm{IV}}-\mathrm{Cu}^{\mathrm{II}}$.

Conclusively, $\mathrm{TA}-\mathrm{Ti}^{\mathrm{IV}}-\mathrm{Cu}^{\mathrm{II}}$ promotes the healing process of the infected wounds due to multiple functions of high hydration, good biocompatibility, and controlled release of antimicrobial agent. Additionally, the gauze adheres to the newly grown tissues on wounds after 3-day use, which occurs very often with traditional dressings when removal of the hydrogel and scab formation ${ }^{35}$. TA- $\mathrm{Ti}^{\mathrm{IV}}-\mathrm{Cu}^{\mathrm{II}}$ showed very weak adhesion to the wounds due to the hydrophilic surfaces and low cell attachment ${ }^{36}$. Moreover, previous research indicates that $\mathrm{Cu}^{\mathrm{II}}$ is well-known as an essential element of angiogenesis ${ }^{37}$, and interacts with many factors involved in the wound healing process ${ }^{38,39}$. Therefore, $\mathrm{Cu}^{\mathrm{II}}$ serves not only an antimicrobial agent, but also a promoter for wound recovery. The responsiveness of the coordinative interaction between galloyl groups and $\mathrm{Cu}^{\mathrm{II}}$ to the changes of $\mathrm{pH}$ and $\mathrm{H}_{2} \mathrm{O}_{2}$ allows spontaneous release of $\mathrm{Cu}^{\mathrm{II}}$ while the wound is infected. The intelligent property and good biocompatibility of the metallogels enable their implementation in the wound management.

\section{Conclusions}

A nature derived metallogel was successfully fabricated by simple gelation through coordinative interaction between $\mathrm{TA}$ and $\mathrm{Ti}^{\mathrm{IV}}$. Antimicrobial metal ions were incorporated into the metallogels by co-gelation. Because of unique characteristics of phenol-metal chelating interactions, the release of metal ions can be triggered by acid and $\mathrm{H}_{2} \mathrm{O}_{2}$, which are endogenously produced due to the immune response of wounds against bacterial infection. Therefore, the antimicrobial agents spontaneously release while wounds get infected. The cytotoxicity of metal

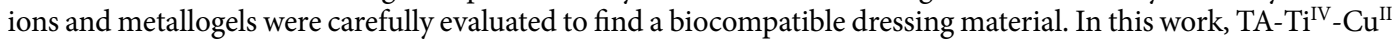
metallogel possesses characteristics of controlled release, biocompatibility, $\mathrm{pH}$ - and $\mathrm{H}_{2} \mathrm{O}_{2}$-dependent antimicrobial property, and weak adhesion to wounds. We expect that the further development will establish TA-based metallogels as a smart system for advanced biomedical applications.

\section{References}

1. Bessa, L. J., Fazii, P., Di Giulio, M. \& Cellini, L. Bacterial isolates from infected wounds and their antibiotic susceptibility pattern: some remarks about wound infection. Int. Wound J. 12, 47-52, https://doi.org/10.1111/iwj.12049 (2015).

2. Tsou, T. L. et al. Poly(2-hydroxyethyl methacrylate) wound dressing containing ciprofloxacin and its drug release studies. J. Mater. Sci.-Mater. Med. 16, 95-100, https://doi.org/10.1007/s10856-005-5954-2 (2005).

3. Bowler, P. G., Duerden, B. I. \& Armstrong, D. G. Wound microbiology and associated approaches to wound management. Clin. Microbiol. Rev. 14, 244-+, https://doi.org/10.1128/cmr.14.2.244-269.2001 (2001).

4. Schneider, L. A., Korber, A., Grabbe, S. \& Dissemond, J. Influence of pH on wound-healing: a new perspective for wound-therapy? Arch. Dermatol. Res. 298, 413-420, https://doi.org/10.1007/s00403-006-0713-x (2007).

5. Lu, Z. T. et al. Hydrogel degradation triggered by $\mathrm{pH}$ for the smart release of antibiotics to combat bacterial infection. New J. Chem. 41, 432-436, https://doi.org/10.1039/c6nj03260e (2017).

6. Handke, L. D. et al. Staphylococcus epidermidis saeR is an effector of anaerobic growth and a mediator of acute inflammation. Infect. Immun. 76, 141-152, https://doi.org/10.1128/iai.00556-07 (2008).

7. Vermeulen, M. et al. Acidosis improves uptake of antigens and MHC class I-restricted presentation by dendritic cells. J. Immunol. 172, 3196-3204, https://doi.org/10.4049/jimmunol.172.5.3196 (2004).

8. Rahman, I., Biswas, S. K. \& Kirkham, P. A. Regulation of inflammation and redox signaling by dietary polyphenols. Biochem. Pharmacol. 72, 1439-1452, https://doi.org/10.1016/j.bcp.2006.07.004 (2006).

9. Vatansever, F. et al. Antimicrobial strategies centered around reactive oxygen species - bactericidal antibiotics, photodynamic therapy, and beyond. Fems Microbiol. Rev. 37, 955-989, https://doi.org/10.1111/1574-6976.12026 (2013).

10. Roy, S., Khanna, S., Nallu, K., Hunt, T. K. \& Sen, C. K. Dermal wound healing is subject to redox control. Mol. Ther. 13, 211-220, https://doi.org/10.1016/j.ymthe.2005.07.684 (2006).

11. Zhu, G. Y., Wang, Q., Lu, S. L. \& Niu, Y. W. Hydrogen Peroxide: A Potential Wound Therapeutic Target? Med. Princ. Pract. 26, 301-308, https://doi.org/10.1159/000475501 (2017).

12. Liu, F. et al. Smart $\mathrm{H}_{2} \mathrm{O}_{2}$-Responsive Drug Delivery System Made by Halloysite Nanotubes and Carbohydrate Polymers. ACS Appl. Mater. Interfaces 9, 31626-31633, https://doi.org/10.1021/acsami.7b10867 (2017).

13. Saravanakumar, G., Kim, J. \& Kim, W. J. Reactive-Oxygen-Species-Responsive Drug Delivery Systems: Promises and Challenges. Adv. Sci. 4, 19, https://doi.org/10.1002/advs.201600124 (2017).

14. Rahim, M. A. et al. Metal-Phenolic Supramolecular Gelation. Angew. Chem.-Int. Edit. 55, 13803-13807, https://doi.org/10.1002/ anie.201608413 (2016).

15. Casey, A. L. et al. Role of copper in reducing hospital environment contamination. J. Hosp. Infect. 74, 72-77, https://doi. org/10.1016/j.jhin.2009.08.018 (2010).

16. Jaiswal, S., McHale, P. \& Duffy, B. Preparation and rapid analysis of antibacterial silver, copper and zinc doped sot-gel surfaces. Colloid Surf. B-Biointerfaces 94, 170-176, https://doi.org/10.1016/j.colsurfb.2012.01.035 (2012).

17. Lemire, J. A., Harrison, J. J. \& Turner, R. J. Antimicrobial activity of metals: mechanisms, molecular targets and applications. Nat. Rev. Microbiol. 11, 371-384, https://doi.org/10.1038/nrmicro3028 (2013).

18. Holten-Andersen, N. et al. pH-induced metal-ligand cross-links inspired by mussel yield self-healing polymer networks with nearcovalent elastic moduli. Proc. Natl. Acad. Sci. USA 108, 2651-2655, https://doi.org/10.1073/pnas.1015862108 (2011).

19. Sedo, J., Saiz-Poseu, J., Busque, F. \& Ruiz-Molina, D. Catechol-Based Biomimetic Functional Materials. Adv. Mater. 25, 653-701, https://doi.org/10.1002/adma.201202343 (2013).

20. Ejima, H. et al. One-Step Assembly of Coordination Complexes for Versatile Film and Particle Engineering. Science 341, 154-157, https://doi.org/10.1126/science.1237265 (2013).

21. Harrington, M. J., Masic, A., Holten-Andersen, N., Waite, J. H. \& Fratzl, P. Iron-Clad Fibers: A Metal-Based Biological Strategy for Hard Flexible Coatings. Science 328, 216-220, https://doi.org/10.1126/science.1181044 (2010).

22. Mazzola, P. G., Jozala, A. F., Novaes, L. C. D., Moriel, P. \& Penna, T. C. V. Minimal inhibitory concentration (MIC) determination of disinfectant and/or sterilizing agents. Braz. J. Pharm. Sci. 45, 241-248, https://doi.org/10.1590/s1984-82502009000200008 (2009).

23. Huang, K. T. et al. Non-sticky and antimicrobial zwitterionic nanocomposite dressings for infected chronic wounds. Biomater. Sci. 5, 1072-1081, https://doi.org/10.1039/c7bm00039a (2017).

24. Sever, M. J. \& Wilker, J. J. Visible absorption spectra of metal-catecholate and metal-tironate complexes. Dalton Trans. 1061-1072, https://doi.org/10.1039/b315811j (2004).

25. Cakar, S. \& Ozacar, M. Fe-tannic acid complex dye as photo sensitizer for different morphological ZnO based DSSCs. Spectroc. Acta Pt. A-Molec. Biomolec. Spectr. 163, 79-88, https://doi.org/10.1016/j.saa.2016.03.031 (2016). 
26. Ninan, N., Forget, A., Shastri, V. P., Voelcker, N. H. \& Blencowe, A. Antibacterial and Anti-Inflammatory pH-Responsive Tannic Acid-Carboxylated Agarose Composite Hydrogels for Wound Healing. ACS Appl. Mater. Interfaces 8, 28511-28521, https://doi. org/10.1021/acsami.6b10491 (2016).

27. Borgias, B. A., Cooper, S. R., Koh, Y. B. \& Raymond, K. N. Synthetic, structural, and physical studies of titanium complexes of catechol and 3,5-di-tertbutylcatechol. Inorganic Chemistry 23, 1009-1016 (1984).

28. Lu, H. W., Zhang, L. M., Liu, J. Y. \& Chen, R. F. Synthesis of an amphiphilic polysaccharide derivative and its micellization for drug release. J. Bioact. Compat. Polym. 23, 154-170, https://doi.org/10.1177/0883911507088272 (2008).

29. Lee, B. P., Narkar, A. \& Wilharm, R. Effect of metal ion type on the movement of hydrogel actuator based on catechol-metal ion coordination chemistry. Sens. Actuator B-Chem. 227, 248-254, https://doi.org/10.1016/j.snb.2015.12.038 (2016).

30. Kholdeeva, O. A. \& Zalomaeva, O. V. Recent advances in transition-metal-catalyzed selective oxidation of substituted phenols and methoxyarenes with environmentally benign oxidants. Coord. Chem. Rev. 306, 302-330, https://doi.org/10.1016/j.ccr.2015.07.019 (2016).

31. Lu, Y. et al. Multifunctional Copper-Containing Carboxymethyl Chitosan/Alginate Scaffolds for Eradicating Clinical Bacterial Infection and Promoting Bone Formation. ACS Appl. Mater. Interfaces 10, 127-138, https://doi.org/10.1021/acsami.7b13750 (2018).

32. Battistoni, A. et al. Increased expression of periplasmic $\mathrm{Cu}, \mathrm{Zn}$ superoxide dismutase enhances survival of Escherichia coli invasive strains within nonphagocytic cells. Infect. Immun. 68, 30-37, https://doi.org/10.1128/iai.68.1.30-37.2000 (2000).

33. Li, M. et al. Toward a Molecular Understanding of the Antibacterial Mechanism of Copper-Bearing Titanium Alloys against Staphylococcus aureus. Adv. Healthc. Mater. 5, 557-566, https://doi.org/10.1002/adhm.201500712 (2016).

34. Cho, M., Kim, J., Kim, J. Y., Yoon, J. \& Kim, J. H. Mechanisms of Escherichia coli inactivation by several disinfectants. Water Res. 44, 3410-3418, https://doi.org/10.1016/j.watres.2010.03.017 (2010).

35. Lalani, R. \& Liu, L. Y. Electrospun Zwitterionic Poly(Sulfobetaine Methacrylate) for Nonadherent, Superabsorbent, and Antimicrobial Wound Dressing Applications. Biomacromolecules 13, 1853-1863, https://doi.org/10.1021/bm300345e (2012).

36. Huang, C. J., Chu, S. H., Wang, L. C., Li, C. H. \& Lee, T. R. Bioinspired Zwitterionic Surface Coatings with Robust Photostability and Fouling Resistance. ACS Appl. Mater. Interfaces 7, 23776-23786, https://doi.org/10.1021/acsami.5b08418 (2015).

37. Wang, X. J. et al. Biocomposites of copper-containing mesoporous bioactive glass and nanofibrillated cellulose: Biocompatibility and angiogenic promotion in chronic wound healing application. Acta Biomater. 46, 286-298, https://doi.org/10.1016/j. actbio.2016.09.021 (2016)

38. Gerard, C., Bordeleau, L. J., Barralet, J. \& Doillon, C. J. The stimulation of angiogenesis and collagen deposition by copper. Biomaterials 31, 824-831, https://doi.org/10.1016/j.biomaterials.2009.10.009 (2010).

39. Sen, C. K. et al. Copper-induced vascular endothelial growth factor expression and wound healing. Am. J. Physiol.-Heart Circul. Physiol. 282, H1821-H1827, https://doi.org/10.1152/ajpheart.01015.2001 (2002).

\section{Acknowledgements}

We acknowledged the financial support for this work provided by the Ministry of Science and Technology (MOST 105-2628-E-008 -007 -MY3).

\section{Author Contributions}

H.T.P.A., C.M.H. and C.J.H. have made substantial contribution to conception and design of the study. H.T.P.A. performed the experiments. H.T.P.A. and C.J.H. have made substantial contributions for analysis and interpretation of data. H.T.P.A. and C.J.H. wrote the manuscript and prepared the figures, which are critically reviewed by C.M.H.

Additional Information

Supplementary information accompanies this paper at https://doi.org/10.1038/s41598-019-47978-9.

Competing Interests: The authors declare no competing interests.

Publisher's note: Springer Nature remains neutral with regard to jurisdictional claims in published maps and institutional affiliations.

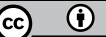

Open Access This article is licensed under a Creative Commons Attribution 4.0 International License, which permits use, sharing, adaptation, distribution and reproduction in any medium or format, as long as you give appropriate credit to the original author(s) and the source, provide a link to the Creative Commons license, and indicate if changes were made. The images or other third party material in this article are included in the article's Creative Commons license, unless indicated otherwise in a credit line to the material. If material is not included in the article's Creative Commons license and your intended use is not permitted by statutory regulation or exceeds the permitted use, you will need to obtain permission directly from the copyright holder. To view a copy of this license, visit http://creativecommons.org/licenses/by/4.0/.

(C) The Author(s) 2019 